\title{
MINERALOGY AND GEOCHEMISTRY OF PEROVSKITE-RICH PYROXENITES.
}

Mariano, ${ }^{(1)}$ Anthony N. and Mitchell, ${ }^{(2)}$ Roher $H$.

(1) 48 Page Brook Road, Carlisle, MA 01741; (2) Department of Geology, Lakehead University, Thunder Bay, Ontario, P7B 5E1.

\section{PEROVSKITE PYROXENITES}

Four carbonatite-pyroxenite complexes as Periphery of the Parana Basin, Brazil include unitg wist ozo grade accumulations of titanium in the form of anatise. The anatase is derived from the weathering of perovskit, on zoxenltes.

The clrcular structures of Catalão I, Serra Negra and Tapira contain perovskite pyroxenites as annul1 located between central carbonatite cores and surrounding domed precambrian sediments which are locally fenitized and silicified. salitre I and II are sateliltes of the serra Negra complex. Sal1tre I 1s oval-shaped and consists of pyroxentte and a small apatite carbonatite. Salitre II is a clrcular plug consisting Fredominantly of pyroxenite transected by thin carbonatite velns and lamprophyre (olivine phlogopitite) dikes.

In some areas of these complexes pyroxenlte grades into glimmerlte, and the pxesence of inclusions of apatite, calcite, magnetite and salite in phlogopite indicates the primary nature of the glimmerite. Magnetite and perovskite occur as cumulus aggregates, disseminations and bands that alternate with apatite, calcite and pyroxene layers. Apatite and magmatic calcite are always present.

The object of this study 18 to demonstrate that perovskite pyroxen1tes are early-formed members of this type of alkaline complex and to document the transformation of these rocks into supergene anatase ores.

PYROXENES

Pyroxene compositional variation 18 of use in assessing the realtive degree of evolution of individual rock units within alkaline complexes. The typical evolutionary trend is one of Iron enrichment. In all cases the most primitive compositions similar pyroxene compositional trends are found in undersaturated and oversaturated complexes. Which trend is followed depends more on the peralkalinity and oxygen fugaclty than the degree of s1lica sacucation. Pyroxenes from the Brazilian perovikite pyoxenite complexes have diopside-salitic compositions with low acmlte and hedenbergite contents. Many of the pyroxenes are pleochroic in shades of brown-green. Grain margins and areas 
adjacent to fractures and cleavages exhibit a stronger green pleochroism and are slightly richer in hedenbergite. Many pyroxenes contain sagenitic-textured magnetite inclusions. Pyroxenes from salitre I are less evolved than those of salitre II. Pyroxen. : from Tapira and Iron H1ll are the most evolved of those examined. All pyroxenes are however relatively nevolved compared to the overall pyroxene compositional trends Thiobservation demonstrates that perovskite pyroxenites must 06 arly-formed members of this type of alkaline complex. Ter.-al studies suggest that they represent cumulates and are , dilkely to be metasomites.

\section{PEROVSKITES}

perovikite compositions reflect the degree of evolution of their host magma and the type of magma from which they crystallized. Early-formed perovskites are close to calclum t1tanate (perovskite and member) in composition. W1th evolution calcium may be replaced by $\mathrm{Na}$, Sr and REE while $\mathrm{Ti} 1 \mathrm{~g}$ replaced by $\mathrm{Nb}$. Compositional evolution is thus typically from perovekite towards lueshite or loparite. Perovskites in the Brazllian and Afrlkander perovskite pyroxenites follow the trend towards loparite. Early-formed perovskites are perovskite with low REE contents. These show textural evidence of reaction with late stage fluids leading to the development of REE enriched rims. In some cases manties of loparite are developed upon cores of the less-evolved perovskite. Rare earth enrichment is related to the clrculation of late-stage hyorothermal flu1ds. The perovgkites In terms of their overall compositions are unevolved, confirming the conclusions derived from the pyroxene compositional trends tat perovskite pyroxenites are unevolved members of these complexes. Significant $\mathrm{Sr}$ and $\mathrm{Na}$ enrichment does not occur in these perovskites and they thus differ from perovskites in carbonatites.

\section{ANATASE AND RHABDOPHANE}

Perovskite pyroxenltes are an 1mportant source o: T1 where intense lateritic weathering has led to decalcification of perovskite. In the Brazilian complexes anatase is concentrated in the zone of weathering. At deeper levels residual cores of perovskite are found within anatase grains. Below the zone of weathering only fresh perovskite is found. Electron microscopy showg that the anatase displays a platy hablt. Aggregations of plates commonly form rosettes. The altered rocks are very porous as all of the components of the pyroxenes and micas orlginally " "sr'- re removed during the later" ation process. ol" Ions pt - $2 g$ through the anatase mat: $2 x$ typically precil lt te mic. stalline aggregates of rha: aphane cerlandte, monazlto and andalite-group minerals. The rare earths are der" id primaxily from the decomposed perovskite, and the phosphate from apatite. 


\section{MICAS}

The compositions of micas parallel those of pyroxenes in showing the relative degree of evolution of the pyroxen1tes. Rocks from Tapira are the most-evolved and those fror: salitre I the least-evolved. Micas within each complex are zoned ar.a exhibit a trend of decreasing alumina from core to ma: $n$. This trand represents evolution from phlogopite towards tetraferrlphlogoplte.

\section{OLIVINES}

Olivines in associated perovskite olivinitej 8 magnesian and unevolved. At Salitre I they contain from $10-12$ wt. 8 Feo and have negligible CaO (< 0.3 wt. $\%$ ) and Mno contents (< 0.5 wt.8). Salitre II olivines range in Feo content from $8-15$ wt. 8 . 